\title{
Effect of lipoic acid on paraoxonase-1 and paraoxonase-3 protein levels, mRNA expression and arylesterase activity in liver hepatoma cells
}

\author{
Eray Ozgun ${ }^{1}$, Gulben Sayilan Ozgun ${ }^{1}$, Kiymet Tabakcioglu ${ }^{2}$, Selma Suer Gokmen ${ }^{1}$, Necdet Sut $^{3}$ \\ and Sevgi Eskiocak ${ }^{1}$ \\ ${ }^{1}$ Department of Medical Biochemistry, Trakya University School of Medicine, 22030 Edirne, Turkey \\ ${ }^{2}$ Department of Medical Biology, Trakya University School of Medicine, 22030 Edirne, Turkey \\ ${ }^{3}$ Department of Biostatistics and Medical Informatics, Trakya University School of Medicine, 22030 Edirne, Turkey
}

\begin{abstract}
Paraoxonase-1 (PON1) and paraoxonase-3 (PON3) are anti-atherosclerotic enzymes, synthesized primarily in liver and bound to HDL in circulation. The aim of the present study was to investigate the effects of therapeutic doses of lipoic acid on PON1 and PON3 protein levels, mRNA expression and arylesterase activity in liver. We treated HepG2 cells with 10, 40 and $200 \mu \mathrm{M}$ lipoic acid for $72 \mathrm{~h}$. Cell viability was evaluated by 3-(4,5-dimethyl-2-thiazolyl)-2,5-diphenyl-2Htetrazolium bromide assay. PON1 and PON3 protein levels were measured by Western blotting, their mRNA expression was measured by quantitative PCR and arylesterase activity was measured spectrophotometrically. $200 \mu \mathrm{M}$ lipoic acid caused a significant increase on PON1 and PON3 protein levels and arylesterase activity as compared with control, $10 \mu \mathrm{M}$ and $40 \mu \mathrm{M}$ lipoic acidtreated cells. $200 \mu \mathrm{M}$ lipoic acid also caused a significant decrease on PON1 mRNA expression whereas on a significant increase PON3 mRNA expression as compared with control, $10 \mu \mathrm{M}$ and $40 \mu \mathrm{M}$ lipoic acid-treated cells. Our study showed that although lipoic acid up-regulates PON3 but down-regulates PON1 mRNA expression, it increases both PON1 and PON3 protein levels and arylesterase activity in HepG2 cells. We can report that lipoic acid may be useful for preventing atherosclerosis at therapeutic doses.
\end{abstract}

Key words: Lipoic acid - Paraoxonase-1 - Paraoxonase-3 - Arylesterase - Liver

\section{Introduction}

Paraoxonase-1 (PON1) and paraoxonase-3 (PON3) are the members of paraoxonase enzyme family which consists of three genes: PON1, PON2 and PON3 and are mainly synthesized by the liver (Précourt et al. 2011). All three proteins have peroxidase, lactonase and arylesterase activity and are capable of hydrolyzing oxidized phospholipids. In circulation, both PON1 and PON3 enzymes are bound to high density lipoprotein (HDL) and shows antioxidant properties (Draganov et al. 2000; Rosenblat et al. 2003; Précourt et al. 2011). PON1 prevents the development of atherosclerosis by protecting LDL against to oxidation and reducing macrophage foam cell formation (Aviram and Rosenblat 2004).

Correspondence to: Eray Ozgun, Department of Medical Biochemistry, Trakya University School of Medicine, 22030 Edirne, Turkey E-mail: drozgune@hotmail.com
On the other hand, it is known that the formation of mildly oxidized low density lipoprotein (LDL) and therefore the induction of monocyte chemotactic activity is prevented by PON3 (Reddy et al. 2001). PON1 activities were shown to be regulated both genetically and by diet (Précourt et al. 2011).

Lipoic acid is synthesized from octanoic acid and cysteine in mitochondria (Golbidi et al. 2011) and is primarily metabolized in the liver (Goraca et al. 2011). Lipoic acid shows direct and indirect antioxidant properties (Rochette et al. 2013) and has been proposed as a potent antioxidant especially for diabetes mellitus, cardiovascular and autoimmune diseases and cancer treatment (Goraca et al. 2011).

In our previous study, we reported that lipoic acid prevents an increase in lipid peroxidation of the liver; therefore it has protective effects against to hepatic ischemia/reperfusion injury in rats (Ozgun et al. 2014). In another study, we also reported that lipoic acid treatment causes an increase in serum PON1 and PON3 protein levels and enzyme activities 
in diabetic rats (Ozgun et al. 2016). Despite several previous reports on the effects of lipoic acid on paraoxonase enzymes protein and activity, no study has ever been performed to specifically examine the effect of lipoic acid on PON1 and PON3 mRNA expression.

The aim of the present study was to investigate the effects of therapeutic doses of lipoic acid on PON1 and PON3 protein levels, mRNA expression and arylesterase activity in liver, the major source of these enzymes. For this purpose, we used the HepG2 cells which are commercial human liver hepatoma cells. HepG2 cells are frequently used as in vitro models for human hepatocytes in previous studies (Jaichander et al. 2008; Kockar et al. 2010; Cheng et al. 2013).

Following oral administration of $600 \mathrm{mg}$ lipoic acid, its mean peak plasma level has been found as approximately $10 \mu \mathrm{M}$. On the other hand, following intravenous administration of 200 and $600 \mathrm{mg}$ lipoic acid, its mean peak plasma level has been found as approximately 40 and $200 \mu \mathrm{M}$, respectively (Moini et al. 2002). Taking into consideration the above findings, we investigated the effect of 10, 40 and $200 \mu \mathrm{M}$ lipoic acid on PON1 and PON3 protein, gene expression and arylesterase activity in HepG2 cells.

The present study is also the first report investigating the effect of therapeutic plasma concentrations of lipoic acid on PON1 and PON3 protein, gene expression and arylesterase activity in liver.

\section{Materials and Methods}

\section{Chemicals}

Human HepG2 cells were purchased from ATCC (Middlesex, UK). Minimum Essential Medium with Glutamin, fetal bovine serum, antibiotic-antimycotic, sodium pyruvate, trypsin-EDTA, RNA isolation kit, High-Capacity cDNA reverse transcription kit, TaqMan probes for PON1, PON3 and GAPDH and HRP chemiluminescent substrate were purchased from Thermo Fisher (Waltham, MA, USA). PON1, PON3, alpha tubulin primary antibodies and goat anti-mouse IgG H\&L horseradish peroxidase secondary antibody were purchased from Abcam (Cambridge, UK). RIPA lysis buffer system was purchased from Santa Cruz (Heidelberg, Germany). Polyvinylidene fluoride (PVDF) membrane was purchased from Bio-Rad (Hercules, CA, USA). Other chemicals were purchased from Sigma-Aldrich Co. (St. Louis, MO, USA) or Merck (Darmstadt, Germany). All reagents were of analytical grade.

\section{Cell culture and experimental design}

HepG2 cells were cultured in minimum essential medium with glutamin containing $10 \%$ fetal bovine serum, $1 \%$ so- dium pyruvate and $1 \%$ antibiotic-antimycotic (100 units/ml penicillin and $100 \mu \mathrm{g} / \mathrm{ml}$ streptomycin and $25 \mu \mathrm{g} / \mathrm{ml}$ of Gibco Amphotericin B) in a humidified environment at $37^{\circ} \mathrm{C}$ and $5 \% \mathrm{CO}_{2}$ atmosphere.

HepG2 cells were divided into four groups: control cells (cultured in medium without lipoic acid for $72 \mathrm{~h}$ ), $10 \mu \mathrm{M}$ lipoic acid-treated cells (cultured with $10 \mu \mathrm{M}$ of lipoic acid for $72 \mathrm{~h}$ ), $40 \mu \mathrm{M}$ lipoic acid-treated cells (cultured with $40 \mu \mathrm{M}$ of lipoic acid for $72 \mathrm{~h}$ ) and $200 \mu \mathrm{M}$ lipoic acid-treated cells (cultured with $200 \mu \mathrm{M}$ of lipoic acid for $72 \mathrm{~h}$ ). Lipoic acid was dissolved in DMSO; DMSO concentration was $0.2 \%$ in all experimental mediums of groups. Culture mediums were refreshed every $24 \mathrm{~h}$ in all 72-h experiments. All the experiments were repeated at least three times.

\section{Cell viability assays}

Effect of lipoic acid on cell viability was evaluated by 3-(4,5-dimethyl-2-thiazolyl)-2,5-diphenyl-2H-tetrazolium bromide (MTT) assay (Mosmann 1983). $10^{4}$ cells were seeded into the 96 well plates. Cells were treated with lipoic acid $(10,40$ and $200 \mu \mathrm{M})$ for 72 hours. At the end of treatment, mediums were removed and $10 \mu \mathrm{l}$ of MTT $(5 \mathrm{mg} /$ $\mathrm{ml}$ ) solved in phosphate-buffered saline (PBS) and $100 \mu \mathrm{l}$ of medium without phenol red were added to each well. Cells were then incubated for 4 hours in a humidified environment at $37^{\circ} \mathrm{C}$ and $5 \% \mathrm{CO}_{2}$ atmosphere. MTT-containing medium was then removed and formazan crystals were then dissolved by adding $200 \mu \mathrm{L}$ DMSO and $25 \mu \mathrm{l}$ Sorensen buffer ( $0.1 \mathrm{M}$ glycine, $0.1 \mathrm{M}$ sodium chloride equilibrated to $\mathrm{pH} 10.5$ with $0.1 \mathrm{M} \mathrm{NaOH}$ ). Optical density of plates were measured using a microplate reader at 570/630 nm (Ahmadian et al. 2009). Optical density of each sample was then compared with the mean optical density value of control group optical density.

\section{Western blot analysis of PON1 and PON3 proteins}

Cells were seeded into $75 \mathrm{~cm}^{2}$ flask. After the cells reached $70-80 \%$ confluence, they were treated with lipoic acid (10, 40 and $200 \mu \mathrm{M}$ ) for $72 \mathrm{~h}$. Following the treatments, cells were scrapped with RIPA lysis buffer system. Samples were homogenized and then centrifuged at $4^{\circ} \mathrm{C}$ for 10 minutes at $15,000 \times g$ (Beltowski et al. 2005). Supernatants were used for protein determination and Western blotting. Protein concentrations were measured according to Lowry et al. (1951) by using bovine serum albumin as standard.

$30 \mathrm{mg}$ of total protein was separated by $4-8 \%$ sodium dodecyl sulfate-polyacrylamide gel electrophoresis and transferred to PVDF membrane by using semi-dry blotting system. Membranes were blocked with 5\% skim milk powder for $1 \mathrm{~h}$ at room temperature. After blocking, mem- 
branes were incubated with monoclonal primary antibodies (PON1:1/1000 dilution and PON3:1/1000 dilution) overnight at $4^{\circ} \mathrm{C}$ and then with secondary antibody (HRP goat anti-mouse: 1/10000 dilution) at room temperature for $1 \mathrm{~h}$. PON1 and PON3 protein bands were visualised by using ECL detection system with HRP chemiluminescent substrate and were quantified by Image J (Schneider et al. 2012). Results were calculated relative to alpha-tubulin as loading control and expressed as fold change relative to control for each blot.

\section{PON1 and PON3 mRNA expression}

Cells were seeded into $25 \mathrm{~cm}^{2}$ flask. After the cells reached $70-80 \%$ confluence, they were treated with lipoic acid (10, 40 and $200 \mu \mathrm{M})$ for $72 \mathrm{~h}$. RNA isolations and PCR reactions were performed at the laboratories of the Technology Research and Development Centre of Trakya University (TUTAGEM). RNA was isolated from cells by using commercial RNA isolation kit and cDNA was generated from $1 \mathrm{mg}$ of total RNA by using commercial high-capacity cDNA reverse transcription kit. These reaction products were subject to quantitative PCR by using TaqMan gene expression assays for PON1 and PON3. GAPDH was used as housekeeping gene.

\section{Arylesterase activity}

Cells were seeded and treated, cell lysates were prepared and protein concentrations were measured in western blotting analysis as described above, except cells were scrapped with $50 \mathrm{mM}$ Tris- $\mathrm{HCl}$ buffer $(\mathrm{pH}=8)$ containing $1 \mathrm{mM} \mathrm{CaCl}_{2}$ and $1 \%$ protease inhibitor cocktail, instead of RIPA lysis buffer system to avoid the inhibition of enzyme activity. Arylesterase activity was measured according to the method of Gan et al. (1991) by modifying substrate concentration. Arylesterase activity was determined by the measuring initial rate of substrate hydrolysis at $270 \mathrm{~nm}$ in the assay mixture containing $1 \mathrm{mM} \mathrm{CaCl}_{2}, 10 \mathrm{mM}$ phenylacetate in $50 \mathrm{mM}$ Tris- $\mathrm{HCl}$ buffer ( $\mathrm{pH}$ 8.0). Measurements were performed at $25^{\circ} \mathrm{C}$ and the blank sample containing incubation mixture without cell lysate was run simultaneously for correction of spontaneous substrate breakdown. Results were calculated relative to total protein levels and expressed as fold change relative to control.

\section{Statistical analysis}

Results were given as means \pm standard deviation (SD). The One-Way ANOVA test was used for comparison of biochemical parameters among the groups, and then, Tukey or Tamhane post-hoc tests were used for multiple comparisons when the significant difference obtained. SPSS 20.0 (IBM
SPSS Inc., Chicago, IL, USA) statistical software was used for statistical analysis. $p<0.05$ was considered as statistically significant.

\section{Results}

The mean percentage of cell viabilities of lipoic acid-treated groups were $139 \%$ for $10 \mu \mathrm{M}$ lipoic acid-treated cells, $130 \%$ for $40 \mu \mathrm{M}$ lipoic acid-treated cells and $124 \%$ for $200 \mu \mathrm{M}$ lipoic acid-treated cells. Lipoic acid (10, 40, $200 \mu \mathrm{M})$ treatment caused a significant increase on cell viabilities as compared with control ( $p<0.001$ for all). Cell viabilities caused by $200 \mu \mathrm{M}$ lipoic acid was significantly lower than those of $10 \mu \mathrm{M}$ lipoic acid ( $p<0.001$ for all) (Fig. 1).

PON1 protein levels of lipoic acid-treated groups were 1.06-fold, 1.13-fold and 1.28-fold for 10, 40 and $200 \mu \mathrm{M}$ lipoic acid-treated cells, respectively. PON1 protein levels in $200 \mu \mathrm{M}$ lipoic acid-treated cells were significantly increased as compared to those in control, $10 \mu \mathrm{M}$ and $40 \mu \mathrm{M}$ lipoic acid-treated cells $(p<0.001, p<0.05$ and $p<0.05$, respectively) (Fig. 2A). PON3 protein levels of lipoic acid-treated groups were 0.94 -fold, 1.35-fold and 3.09-fold for 10, 40 and $200 \mu \mathrm{M}$ lipoic acid-treated cells, respectively. $200 \mu \mathrm{M}$ lipoic acid caused a significant increase on PON3 protein levels as compared with control, $10 \mu \mathrm{M}$ and $40 \mu \mathrm{M}$ lipoic acid $(p<$ 0.05 for all) (Fig. 2A).

PON1 mRNA expression of lipoic acid-treated groups were 1.03-fold, 1.10-fold and 0.74-fold for 10, 40 and $200 \mu \mathrm{M}$ lipoic acid-treated cells, respectively. PON1 mRNA expression in $200 \mu \mathrm{M}$ lipoic acid treated cells were significantly decreased as compared to those in control, $10 \mu \mathrm{M}$ and $40 \mu \mathrm{M}$ lipoic acid-treated cells $(p<0.05$ for all $)$

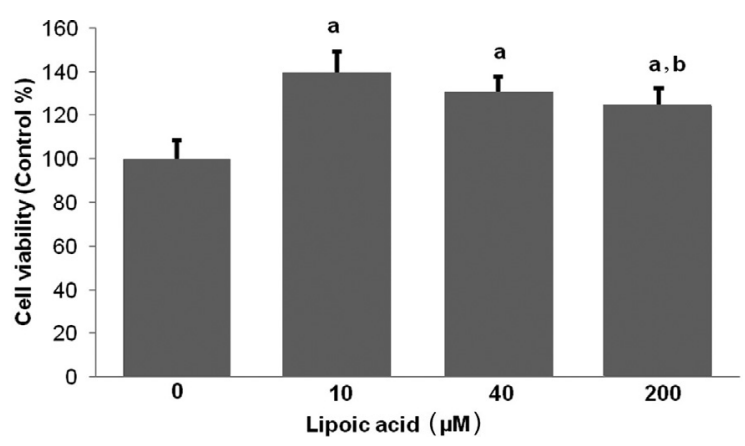

Figure 1. Effect of lipoic acid treatment for $72 \mathrm{~h}$ on the viability in HepG2 cells. Results are expressed as mean \pm SD for experimental groups ( $n=12$ for all groups). Effects of lipoic acid was analyzed by one-way analysis of variance. Tukey test was performed for multiple comparisons between experimental groups. ${ }^{\mathrm{a}} p<0.001 v \mathrm{~s}$. control; ${ }^{\mathrm{b}} p<0.001 v s .10 \mu \mathrm{M}$ lipoic acid-treated cells. 
$\mathbf{A}$
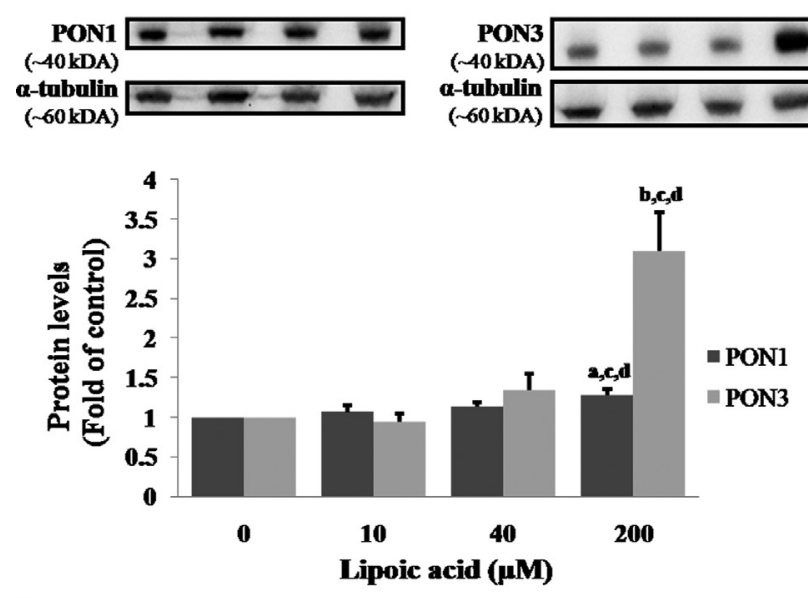

B

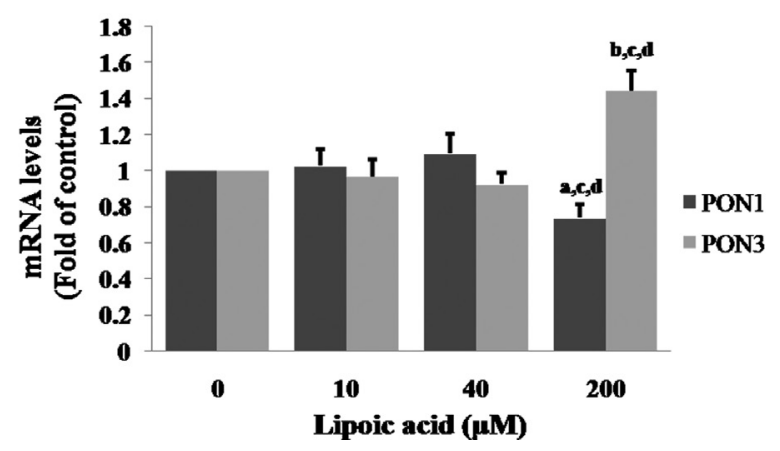

Figure 2. Effect of lipoic acid treatment for $72 \mathrm{~h}$ on PON1 and PON3 protein (A) and mRNA levels (B) in HepG2 cells. Results are expressed as mean \pm SD for experimental groups $(n=4$ for protein and $n=6$ for mRNA levels for all groups). Effects of lipoic acid was analyzed by one-way analysis of variance. Tukey test was performed for multiple comparisons between experimental groups for PON1 protein levels. Tamhane test was performed for multiple comparisons between experimental groups for PON1 mRNA levels and PON3 protein and mRNA levels. ${ }^{\mathrm{a}} p<0.001,{ }^{\mathrm{b}} p<0.05 v s$. control; ${ }^{\mathrm{c}} p<0.05 v s .10 \mu \mathrm{M}$ lipoic acid-treated cells; ${ }^{\mathrm{d}} p<0.05 v$. $40 \mu \mathrm{M}$ lipoic acid-treated cells.

(Fig. 2B). PON3 mRNA expression of lipoic acid-treated groups were 0.97 -fold, 0.92 -fold and 1.44-fold for 10, 40 and $200 \mu \mathrm{M}$ lipoic acid-treated cells, respectively. $200 \mu \mathrm{M}$ lipoic acid caused a significant increase on PON3 mRNA expression as compared with control, $10 \mu \mathrm{M}$ and $40 \mu \mathrm{M}$ lipoic acid $(p<0.001, p<0.05$ and $p<0.05$, respectively) (Fig. 2B).

Arylesterase activities of lipoic acid-treated groups were 1.00-fold, 1.06-fold and 1.36-fold for 10, 40 and $200 \mu \mathrm{M}$ lipoic acid-treated cells, respectively. $200 \mu \mathrm{M}$ lipoic acid caused a significant increase on arylesterase activity as compared with control, $10 \mu \mathrm{M}$ and $40 \mu \mathrm{M}$ lipoic acid $(p<0.001$ for all) (Fig. 3).

\section{Discussion}

Paraoxonases are antioxidant enzymes which are able to catalyze hydrolysis of oxidized phospholipids ( $\mathrm{Ng}$ et al. 2005). Although most known activities of paraoxonase enzyme family are paraoxonase and arylesterase activities, these enzymes are primary lactonases and unlike PON1, PON3 have no paraoxonase and limited arylesterase activity (Précourt et al. 2011). PON1 and PON3 both have antioxidant properties and by protecting LDL against to oxidation, they prevent the development of atherosclerosis (Reddy et al. 2001; Aviram and Rosenblat 2004). Oxidized lipids in oxidized LDL are known to inactivate PON1. Dietary antioxidant can effect paraoxonase levels and activities by reducing oxidative stress (Aviram 2003). Antioxidants significantly reduce the content of lipoprotein-related lipid peroxides and protect PON1 activities (Aviram et al. 1999). Dietary antioxidant can also effect the gene expression of paraoxonases (Aviram 2003).

Lipoic acid is found in very small amounts in mammalian tissues, not in free form but bound to particular dehydrogenase as a cofactor (Golbidi et al. 2011). Because it is able to quench reactive oxygen species, chelate metal ions and reduce the oxidized forms of other antioxidants, it is known as an important antioxidant (Packer et al. 2001). There is an increasing interest in using lipoic acid as a potent antioxidant for the treatment of diabetes and cardiovascular diseases (Goraca et al. 2011).

Only a few studies have focused on the effect of lipoic acid on serum PON1 enzyme activities (Yi and Maeda 2006; Gavrovskaia et al. 2008). We previously showed for the first time that lipoic acid causes an increase in serum PON1 and $\mathrm{PON} 3$ protein levels and activities in diabetic rats (Ozgun et

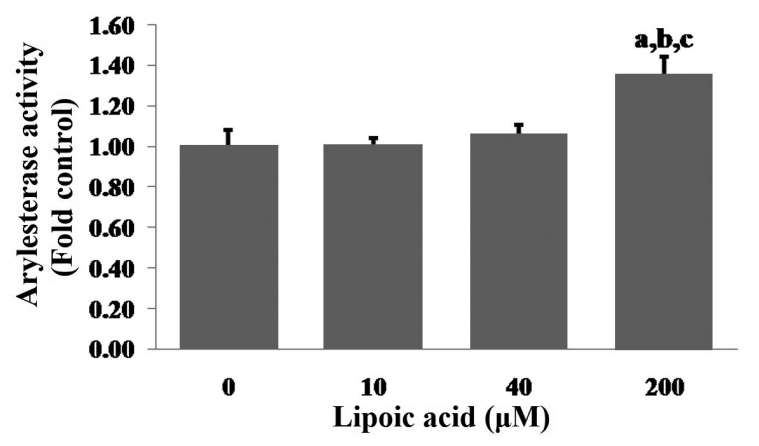

Figure 3. Effect of lipoic acid treatment for $72 \mathrm{~h}$ on arylesterase activity in HepG2 cells. Results are expressed as mean \pm SD for experimental groups ( $n=9$ for all groups). Effects of lipoic acid was analyzed by one-way analysis of variance. Tukey test was performed for multiple comparisons between experimental groups. ${ }^{\mathrm{a}} p<0.001$ vs. control; ${ }^{\mathrm{b}} p<0.001 v s .10 \mu \mathrm{M}$ lipoic acid-treated cells; ${ }^{\mathrm{c}} p<0.001$ vs. $40 \mu \mathrm{M}$ lipoic acid-treated cells. 
al. 2016). Despite several previous reports on the beneficial effects of lipoic acid on cardiovascular diseases (Goraca et al. 2011; Rochette et al. 2013; Koufaki 2014) no study has ever been performed to specifically examine the effects of lipoic acid on PON1 and PON3 gene and protein expression and activities in liver. The present study was designed to investigate the effects of therapeutic doses of lipoic acid on liver PON1 and PON3 gene and protein expression and arylesterase activity in vitro.

Lipoic acid was non-toxic and caused a significant increase on cell viability in HepG2 cells at the dose of 10, 40 and $200 \mu \mathrm{M}$. The present study showed that $200 \mu \mathrm{M}$ lipoic acid has an increasing effect on PON1 protein levels and arylesterase activity while it has a decreasing effect on PON1 mRNA expression in HepG2 cells. The fold increases in PON1 protein levels and arylesterase activities were similar. PON1 is regulated by oxidative stress and has buffer action (Précourt et al. 2011). While PON1 protects LDL from oxidation (Aviram and Rosenblat 2004), it becomes inactivated by oxidized lipids (Reddy et al. 2001). Trudel et al. (2005) reported that lipid peroxidation induced by iron-ascorbic acid causes a decrease on the protein mass of PON1 in liver. In our previous study, we showed that lipoic acid prevents an increase in liver lipid peroxidation in hepatic ischemia/ reperfusion injury (Ozgun et al. 2014).

Lipoic acid may prevent PON1 degradation and therefore repress PON1 mRNA expression by reducing oxidative stress. Our findings indicating that there is an increased in PON1 protein levels and arylesterase activity support to above idea.

PON3 is not a well-known protein such as PON1. It was reported that PON3 is not regulated by oxidized lipids (Reddy et al. 2001). In our study $200 \mu \mathrm{M}$ lipoic acid caused a significant increase on both PON3 protein level and mRNA expression. This finding indicates that lipoic acid induces $P O N 3$ gene expression and supports our previous study which showed that lipoic acid increases serum PON3 protein levels and the increase percent of serum PON3 protein is higher than that of serum PON1 protein in lipoic acid-treated diabetic rats (Ozgun et al. 2016).

Our study showed that, although lipoic acid up-regulates PON3 but down-regulates PON1 mRNA expression, it increases both PON1 and PON3 protein levels and arylesterase activity in HepG2 cells. We can report that lipoic acid may be useful for preventing atherosclerosis at therapeutic doses.

Lipoic acid cause an increase in protein levels of PON3 by the induction of PON3 mRNA expression. On the other hand, an increase in the protein levels of PON1 caused by lipoic acid may be resulted from a decrease in the degradation of PON1 because of a reduction in oxidative stress.

Our findings indicating that lipoic acid induces PON3 mRNA expression but represses PON1 mRNA expression, point out that the regulation of $P O N 1$ gene expression may be differ from that of $P O N 3$ gene expression. Further research should address the precise regulation mechanisms of PON1 and $P O N 3$ gene expression in liver.

The limitation of this paper is not able to show lactonase which is the main activity of PON3 enzyme. Although we attempted to measure paraoxonase activity using paraoxon according to Gan et al. (1991) and lactonase activity using dihydrocoumarin and decanolactone according to Draganov et al. (2000), we were not able to find any results because the activities were below or very close to detection limits of our assays.

Conflict of interest. The authors declare no conflict of interest.

Acknowledgements. This study was supported by Scientific Research Appropriation of Trakya University (TÜBAP 2015/159), Turkey. We would like to thank TÜTAGEM laboratories.

\section{References}

Ahmadian S., Barar J., Saei A. A., Fakhree M. A., Omidi Y. (2009): Cellular toxicity of nanogenomedicine in MCF-7 cell line: MTT assay. J. Vis. Exp. 26, 1191

https://doi.org/10.3791/1191

Aviram M., Rosenblat M., Billecke S., Erogul J., Sorenson R., Bisgaier C. L., Newton R. S., La Du B. (1999): Human serum paraoxonase (PON 1) is inactivated by oxidized low density lipoprotein and preserved by antioxidants. Free Radic. Biol. Med. 26, 892-904

https://doi.org/10.1016/S0891-5849(98)00272-X

Aviram M. (2003): Dietary antioxidants stimulate the expression of paraoxonases which provide protection against atherosclerosis development. Curr. Topics Nutr. Res. 1, 183-191

Aviram M., Rosenblat M. (2004): Paraoxonases 1, 2, and 3, oxidative stress, and macrophage foam cell formation during atherosclerosis development. Free Radic. Biol. Med. 37, 1304-1316

https://doi.org/10.1016/j.freeradbiomed.2004.06.030

Beltowski J., Jamroz-Wiśniewska A., Borkowska E., Wójcicka G. (2005): Differential effect of antioxidant treatment on plasma and tissue paraoxonase activity in hyperleptinemic rats. Pharmacol. Res. 51, 523-532 https://doi.org/10.1016/j.phrs.2005.01.007

Cheng C. C., Hsueh C. M., Chen C. Y., Chen T. H., Hsu S. L. (2013): Interleukin-6 upregulates paraoxonase 1 gene expression via an AKT/NF- $\kappa \mathrm{B}$-dependent pathway. Biochem. Biophys. Res. Commun. 437, 55-61

https://doi.org/10.1016/j.bbrc.2013.06.034

Draganov D. I., Stetson P. L., Watson C. E., Billecke S. S., La Du B. N. (2000): Rabbit serum paraoxonase 3 (PON3) is a high density lipoprotein-associated lactonase and protects low density lipoprotein against oxidation. J. Biol. Chem. 275, 33435-33442

https://doi.org/10.1074/jbc.m004543200

Gan K. N., Smolen A., Eckerson H. W., La Du B. N. (1991): Purification of human serum paraoxonase/arylesterase. Evidence 
for one esterase catalyzing both activities. Drug Metab. Dispos. 19, 100-106

Gavrovskaia L. K., Ryzhova O. V., Safonova A. F., Aleksandrova I. I., Sapronov N. S. (2008): Effect of taurine and thioctacide on carbohydrate metabolism and the antioxydant system in rats with experimental diabetes. Eksp. Klin. Farmakol. 71, 34-35

Golbidi S., Badran M., Laher I. (2011): Diabetes and alpha lipoic acid. Front Pharmacol. 2, 69 https://doi.org/10.3389/fphar.2011.00069

Goraca A., Huk-Kolega H., Piechota A., Kleniewska P., Ciejka E., Skibska B. (2011): Lipoic acid - biological activity and therapeutic potential. Pharmacol. Rep. 63, 849-858 https://doi.org/10.1016/S1734-1140(11)70600-4

Jaichander P., Selvarajan K., Garelnabi M., Parthasarathy S. (2008): Induction of paraoxonase 1 and apolipoprotein A-I gene expression by aspirin. J. Lipid Res. 49, 2142-2148 https://doi.org/10.1194/jlr.M800082-JLR200

Kockar F., Sinan S., Yildirim H., Arslan O. (2010): Differential effects of some antibiotics on paraoxonase enzyme activity on human hepatoma cells (HepG2) in vitro. J. Enzyme Inhib. Med. Chem. 25, 715-719 https://doi.org/10.3109/14756360903555266

Koufaki M. (2014): Therapeutic applications of lipoic acid: a patent review (2011-2014). Expert Opin. Ther. Pat. 24, 993-1005

Lowry O. H., Rosebrough N. J., Farr A. L., Randall R. J. (1951): Protein measurement with the Folin phenol reagent. J. Biol. Chem. 193, 265-275

Moini H., Packer L., Saris N. E. (2002): Antioxidant and prooxidant activities of alpha-lipoic acid and dihydrolipoic acid. Toxicol. Appl. Pharmacol. 182, 84-90

https://doi.org/10.1006/taap.2002.9437

Mosmann T. (1983): Rapid colorimetric assay for cellular growth and survival: application to proliferation and cytotoxicity assays. J. Immunol. Methods 65, 55-63 https://doi.org/10.1016/0022-1759(83)90303-4

Ng C. J., Shih D. M., Hama S. Y., Villa N., Navab M., Reddy S. T. (2005): The paraoxonase gene family and atherosclerosis. Free Radic. Biol. Med. 38, 153-163 https://doi.org/10.1016/j.freeradbiomed.2004.09.035

Ozgun E., Ozgun G. S., Gokmen S. S., Eskıcak S., Sut N., Akınc1 M., Goncu E., Cakır E. (2016): Effect of lipoic acid on serum paraoxonase-1 and paraoxonase- 3 protein levels and activities in diabetic rats. Exp. Clin. Endocrinol. Diabetes (in print) https://doi.org/10.1055/s-0042-101164

Ozgun G. S., Ozgun E., Basaran U. N., Altaner S., Sut N., Eskiocak S. (2014): Protective effects of a-lipoic acid and
L-carnitine in liver ischemia/reperfusion injury. Turk. J. Bioch. 39, 169-175 https://doi.org/10.5505/tjb.2014.02525

Packer L., Kraemer K., Rimbach G. (2001): Molecular aspects of lipoic acid in the prevention of diabetes complications. Nutrition $\mathbf{1 7}, 888-895$ https://doi.org/10.1016/S0899-9007(01)00658-X

Précourt L. P., Amre D., Denis M. C., Lavoie J. C., Delvin E., Seidman E., Levy E. (2011): The three-gene paraoxonase family: physiologic roles, actions and regulation. Atherosclerosis 214, 20-36 https://doi.org/10.1016/j.atherosclerosis.2010.08.076

Reddy S. T., Wadleigh D. J., Grijalva V., Ng C., Hama S., Gangopadhyay A., Shih D. M., Lusis A. J., Navab M., Fogelman A. M. (2001): Human paraoxonase-3 is an HDL-associated enzyme with biological activity similar to paraoxonase- 1 protein but is not regulated by oxidized lipids. Arterioscler. Thromb. Vasc. Biol. 21, 542-547 https://doi.org/10.1161/01.atv.21.4.542

Rochette L., Ghibu S., Richard C., Zeller M., Cottin Y., Vergely C. (2013): Direct and indirect antioxidant properties of $\alpha$-lipoic acid and therapeutic potential. Mol. Nutr. Food Res. 57, $114-125$ https://doi.org/10.1002/mnfr.201200608

Rosenblat M., Draganov D., Watson C. E., Bisgaier C. L., La Du B. N., Aviram M. (2003): Mouse macrophage paraoxonase 2 activity is increased whereas cellular paraoxonase 3 activity is decreased under oxidative stress. Arterioscler Thromb. Vasc. Biol. 23, 468-474 https://doi.org/10.1161/01.ATV.0000059385.95664.4D

Schneider C. A., Rasband W. S., Eliceiri K. W. (2012): NIH Image to ImageJ: 25 years of image analysis. Nat. Methods 9, 671-675 https://doi.org/10.1038/nmeth.2089

Trudel K., Sinnett D., James R. W., Delvin E., Amre D., Seidman E., Levy E. (2005): Iron-ascorbic acid-induced oxidant stress and its quenching by paraoxonase 1 in HDL and the liver: comparison between humans and rats. J. Cell Biochem. 96, 404-411 https://doi.org/10.1002/jcb.20542

Yi X., Maeda N. (2006): alpha-Lipoic acid prevents the increase in atherosclerosis induced by diabetes in apolipoprotein Edeficient mice fed high-fat/low-cholesterol diet. Diabetes 55, 2238-2244

https://doi.org/10.2337/db06-0251

Received: December 2, 2016

Final version accepted: February 2, 2017

First published online: June 27, 2017 


\title{
Evaluation of liposomal carnosine in adjuvant arthritis
}

\author{
Lukáš Slovák $^{1,2}$, Silvester Poništ ${ }^{1}$, Tatiana Fedorova ${ }^{3}$, Anna Logvinenko $^{3}$, Irina Levacheva ${ }^{4}$, \\ Olga Samsonova ${ }^{4}$, Udo Bakowsky ${ }^{4}$, Ludmila Pašková ${ }^{5}$, Tomáš Čavojský ${ }^{5}$, Lia Tsiklauri ${ }^{6}$ \\ and Katarína Bauerová ${ }^{1,7}$ \\ ${ }^{1}$ Institute of Experimental Pharmacology and Toxicology of the Slovak Academy of Sciences, Dúbravská cesta 9, Bratislava, \\ Slovakia \\ ${ }^{2}$ Comenius University Bratislava, Jessenius Faculty of Medicine, Department of Pharmacology, BioMed Martin, Slovakia \\ ${ }^{3}$ Research Center of Neurology, Moscow, Volokolamskoye shosse 80, 125367 Moscow, Russian Federation \\ ${ }^{4}$ Philipps Universität Marburg, Institut für Pharmazeutische Technologie und Biopharmazie, Ketzerbach 63, D-35032 Marburg, \\ Germany \\ ${ }^{5}$ Comenius University in Bratislava, Faculty of Pharmacy, Department of Cell and Molecular Biology of Drugs, Bratislava, \\ Slovakia \\ ${ }^{6}$ Pharmaceutical Technology Department I., Kutateladze Institute of Pharmacochemistry, P. Sarajishvili st 36, Tbilisi 0159, \\ Georgia \\ ${ }^{7}$ Comenius University in Bratislava, Faculty of Pharmacy, Department of Galenic Pharmacy, Bratislava, Slovakia
}

\begin{abstract}
Liposomal carnosine could overcome the problems associated with direct application of this peptide. Anti-inflammatory and antioxidant effects of liposomal and non-liposomal carnosine in adjuvant arthritis were compared. The experiments were done on healthy animals, untreated arthritic animals, arthritic animals with oral administration of carnosine, and with subcutaneous administration of liposomal carnosine, both administered in the same daily dose of $150 \mathrm{mg} / \mathrm{kg}$ b.w. during 28 days. Carnosine reduced hind paw volume on day 28. Both forms markedly decreased interleukin-1 $\beta$, matrix metalloproteinase- 9 and monocyte chemoattractant protein-1 (MCP-1) in plasma on day 14. Only liposomal carnosine reduced significantly MCP-1. Malondialdehyde, 4-hydroxynonenal, resistance to $\mathrm{Fe}^{2+}$-induced oxidation and protein carbonyls were significantly corrected after administration of any form of carnosine. Liposomal carnosine corrected more effectively the oxidative stress in plasma than did carnosine. In brain tissue, our results showed protective ability of both forms of carnosine against oxidation of proteins and lipids. They also corrected the resistance to $\mathrm{Fe}^{2+}$-induced oxidation in arthritic animals. We found that only liposomal carnosine decreased the mRNA expression of inducible nitric oxide synthase in cartilage tissue. It can be concluded that the liposomal drug-delivery system is improving the pharmacological properties of carnosine administered in arthritis.
\end{abstract}

Key words: Liposomes - Adjuvant arthritis - Oxidative stress - Carnosine - Inflammation

\section{Introduction}

Rheumatoid arthritis (RA) is the most common autoimmune inflammatory arthritis in adults (Helmick et al. 2008). Although traditional treatment is reducing the pain

Correspondence to: Katarina Bauerova, Institute of Experimental Pharmacology and Toxicology, Slovak Academy of Sciences, Dubravska cesta 9, 84104 Bratislava, Slovakia

E-mail: katarina.bauerova@savba.sk without toxic pharmacological consequences, it is ineffective in reversing cartilage degradation and only slows it down. Moreover, its potential side effects limit the length of therapy (Cameron et al. 2009). There is thus an urgent need to find new methods and strategies for the treatment of RA. Several researchers reported that antioxidants are potential agents in RA therapeutic management (Khojah et al. 2016; Mateen et al. 2016). In the development of adjuvant arthritis (AA) not only immunological and inflammatory pathological changes are involved, but also the redox ho- 
meostasis is shifted towards increased production of reactive oxygen species (ROS) and reactive nitrogen species (RNS). Recent evidence from animal models of RA emphasized the importance of neutrophils in the initiation and progression of AA (Cross et al. 2006). We assessed ROS production in stimulated neutrophils of arthritic rats and it was found to be increased, with maximum on day 14 and 21 of AA. Neutrophils in whole blood of AA animals reacted excessively to stimulation and produced 6-9 times more ROS (Nosal et al. 2007). We also demonstrated oxidative damage to the tissues in AA: ROS levels in the joint and the spleen were significantly elevated (Drabikova et al. 2009). The control of inflammation in arthritic patients by natural as well as synthetic antioxidants could become a relevant component of antirheumatic prevention and therapy (Bauerová and Bezek 1999). Carnosine ( $\beta$-alanyl-L-histidine) is a naturally occurring antioxidant and cell protector (Boldyrev and Johnson 2002). Carnosine is available as a dietary supplement with no known side effects or identified adverse drug interactions (Min et al. 2008). One of the reasons for the limited use of carnosine as a drug is considered to be its fast metabolism by means of serum and kidney carnosinases. These enzymes quickly decrease the level of carnosine in serum, thus preventing its long-lasting action (Pegova et al. 2000). Our previous study showed a protective effect of carnosine against oxidative damage and also its systemic anti-inflammatory effects (Ponist et al. 2016). Liposomes are nanosized artificial vesicles of spherical shape that can be produced from natural or synthetic phospholipids (Schuber et al. 1998). Encapsulation of antioxidants in liposomes has been shown to improve their therapeutic potential against oxidant-induced tissue injuries, as liposomes evidently facilitate intracellular delivery and extend the retention time of incorporated agents inside the cell. Thus antioxidant liposomes hold great promise in the treatment of many diseases in which oxidative stress plays a significant role (Zacharias 2011). Entrapment of carnosine into liposomes may represent an ameliorative approach to overcome the problems related with direct application of this antioxidant peptide by improving bioavailability in brain lipid tissues and providing protection against carnosinase.

The aim of this study was to examine anti-inflammatory and antioxidant effects of liposomal carnosine in plasma and brain in AA and to compare these effects with its nonliposomal form.

\section{Materials and Methods}

\section{Animals, experimental design and treatments}

Male Lewis rats, weighing 160-180 g, were purchased from the Breeding Farm Dobra Voda (Slovakia) and housed five per cage under standard conditions with food and water ad libitum and a 12-hour-light/12-hour-dark cycle. The experimental protocol was approved by the Ethics Committee of the Institute of Experimental Pharmacology and Toxicology and by the Slovak State Veterinary and Food Administration in accordance with the European Convention for the Protection of Vertebrate Animals Used for Experimental and Other Scientific Purposes and was found in accordance with Slovak legislation. AA was induced by a single intradermal injection of $0.1 \mathrm{ml}$ suspension of heatinactivated Mycobacterium butyricum (Difco Laboratories, Detroit, MI, USA) in incomplete Freund's adjuvant at the base of the tail. The experiments included four groups of animals ( 8 animals in each group): Group 1, healthy animals as reference controls (CO); Group 2, arthritic animals without any drug administration (AA); Group 3, arthritic animals with the administration of carnosine (CARN) $150 \mathrm{mg} / \mathrm{kg}$ b.w. in a daily oral dose during 28 days; and Group 4, arthritic animals with the administration of liposomal carnosine (CARN-L) $150 \mathrm{mg} / \mathrm{kg}$ b.w. in a daily subcutaneous dose during 28 days. Body weight of the rats was regularly measured to calculate the precise application doses before each administration of the given substance. On day 14 , blood samples were taken from the retro-orbital plexus under Zoletil ${ }^{\circledast / x y l a z i n e ~ a n e s t h e s i a . ~ O n ~ d a y ~ 28, ~ t h e ~}$ animals were sacrificed under the same anesthesia and blood for plasma preparations was withdrawn along with brain and cartilage tissue from each rat. All samples were stored at $-80^{\circ} \mathrm{C}$ until biochemical analysis.

\section{Preparation of liposomes by lipid film hydration}

Liposomes were prepared by thin film hydration method. Briefly, sterol lipids and fatty acids were dissolved in an organic solvent to assure a homogeneous lipid mixture. The solution was prepared at $10-20 \mathrm{mg}$ lipid/ml of organic solvent (ethanol 100\%). Then the mixture was evaporated in a rotary evaporator. Carnosine was added to the obtained lipid film in buffer PBS (phosphate buffered saline) solution and finally the heterogeneous system was thoroughly mixed using ultrasonic equipment to obtain liposomes (the ratio drug/lipids was $0.2: 1$ ). All solutions were sterile and the preparation of liposomes was performed in sterile conditions.

\section{Clinical parameter: change of hind paw volume}

The hind paw volume (HPV, \%) increase was calculated as the percentage increase in the HPV on a given experimental day relative to the HPV at the beginning of the experiment. This parameter was recorded on days 1, 14, 21, and 28 with the use of an electronic water plethysmometer (UGO BASILE, Comerio-Varese, Italy). 
Measurement of monocyte chemoattractant protein-1 (MCP-1) in plasma

For determination of plasmatic concentration of MCP-1 an ELISA kit from eBioscience was used. The assay procedure was applied as described in the product manual. An anti-rat MCP-1 monoclonal coating antibody was adsorbed onto microwells. Rat MCP-1 was present in the sample or standard bound to antibodies adsorbed to the microwell; a biotin-conjugated monoclonal anti-rat MCP-1 antibody bound to rat MCP-1 was captured by the first antibody. Streptavidin-HRP was bound to the conjugated anti-rat MCP-1. Following incubation, unbound biotin conjugated anti-rat MCP-1 and Streptavidin-HRP were removed during a wash step and substrate solution reactive with HPR was added to the wells. A colored product was formed in proportion to the amount of soluble rat MCP-1 present in the sample. The reaction was terminated by addition of acid and absorbance was measured at $450 \mathrm{~nm}$ in comparison with reference wavelength $620 \mathrm{~nm}$ (microplate reader MRX II, Dynex, USA). The results were calculated from standard calibration curve on internal standards.

Measurement of interleukin $1 \beta(I L-1 \beta)$ and matrix metalloproteinase 9 (MMP-9) in plasma

For determination of plasmatic concentration of IL- $1 \beta$ and MMP-9, an ELISA kit from R\&D Systems Quantikine was used. The assay procedures were applied as described in the product manuals.

\section{Chemiluminescence measurement of plasma and brain homogenate antioxidant capacity}

The method used was based on the measurement of chemiluminescence $(\mathrm{ChL})$ in brain homogenates and plasma of the experimental animals oxidized by $\mathrm{Fe}^{2+}$ ions added in excess to the reaction medium (Fedorova et al. 1999). To initiate lipid peroxidation (LPO), $2.5 \mathrm{mM} \mathrm{Fe}^{2+}$ ions were added. The initial ChL burst $(h, m V)$ represents the level of pre-existent LPO products (reflects the stationary level of lipid hydroperoxides), the lag period of $\mathrm{Fe}^{2+}$-induced oxidation $(\tau, s)$ characterizes the resistance of the sample against oxidation, dependent on the intrinsic antioxidant capacity of a biological sample. ChL signal was monitored using LKB 1251Chemiluminometer (Sweden) and was expressed in $\mathrm{mV}$ (Dobrota et al. 2005).
Measurement of malondialdehyde in plasma and brain homogenates

Malondialdehyde (MDA) ELISA Kit (Cusabio cat № CSB$\mathrm{E} 08557 \mathrm{~h}$ ) for the quantitative determination of endogenic MDA concentrations in plasma and tissue homogenates was used. The assay employs an inhibition enzyme immunoassay technique. Antibody specific for MDA was pre-coated onto a microplate. Standards and samples were pipetted into the wells with horseradish-peroxidase (HRP) -conjugated MDA. A competitive inhibition reaction between MDA (standards and samples) and HRP-conjugated MDA with the pre-coated antibody specific for MDA was launched - the higher the amount of MDA in samples, the less antibody bound by HRP-conjugated MDA will bind. Following a wash to remove any unbound reagent, a substrate solution was added to the wells and color was developed. The color development was stopped and the intensity was measured.

\section{Measurement of 4-hydroxynonal and protein carbonyls in plasma and brain homogenates}

Determination of oxidative stress parameters was done by using protein carbonyl ELISA Kit (Immundiagnostik AG cat№ K7822) and 4-hydroxynonenal (HNE) ELISA Kit (Cusabio cat № CSB-E16214h). The assay procedures were applied as described in the product manuals.

\section{Total RNA isolation and quantitative RT-PCR}

Total RNA was isolated from the rat cartilage tissue. The cartilage was pulverized in liquid nitrogen followed by RNA extraction with the RNAzol RT (Sigma-Aldrich). RNA was converted into complementary DNA (cDNA) using the PrimeScript RT Reagent Kit (Takara) following the protocols of the manufacturers. Amplification and detection of cDNA of reference and target genes were performed on a 7300 Real-Time PCR System (Applied Biosystems) using HOT FIREPolEvaGreenR qPCR MixPlus (ROX) (Solis Biodyne). Relative mRNA expressions of inducible nitric oxide synthase (iNOS) were analyzed using the $\Delta \Delta$ Ct value method (Winer et al. 1999). $\beta$-actin was used as a reference gene. PCR products were evaluated by melting curve analysis to confirm the specific amplification. The sequences of the primers were designed and checked using Primer 3 and Oligo Analyzer 1.0.3 (Table 1).

Table 1. Primer sequences

\begin{tabular}{lll}
\hline Product & Sense primer $\left(5^{\prime}-3^{\prime}\right)$ & Antisense primer $\left(5^{\prime}-3^{\prime}\right)$ \\
\hline iNOS & AAAACCCCAGGTGCTATTCCC & GTGGTGAAGGGTGTCGTGAA \\
$\beta$-actin & CCGCGAGTACAACCTTCTTG & GCAGCGATATCGTCATCCA \\
\hline
\end{tabular}




\section{Statistical analyses}

Mean and S.E.M. values were calculated for each parameter in each group. Statistically significant differences among treated groups, untreated group and control group were tested using parametric Analysis of variance (ANOVA). After post hoc (Tukey-Kramer) testing, significance designations were specified as follows: extremely significant (** $p<0.001)$, highly significant $\left({ }^{* *} p<0.01\right)$, significant $\left({ }^{*} p<0.05\right)$, and not significant $(p>0.05)$.

\section{Results}

\section{Clinical parameter}

HPV of arthritic animals increased during the experiment in comparison to the control group on all days monitored. The highest increase was observed at the end of the experiment - day 28. Carnosine and liposomal carnosine reduced this parameter, but this effect was not statistically significant, except on day 28 when carnosine significantly reduced HPV (Fig. 1).

\section{Inflammatory parameters in plasma evaluated on day 14}

The level of IL-1 $\beta$ in untreated arthritic animals was increased approximately 12 times on day 14 when compared to healthy controls. Carnosine and liposomal carnosine

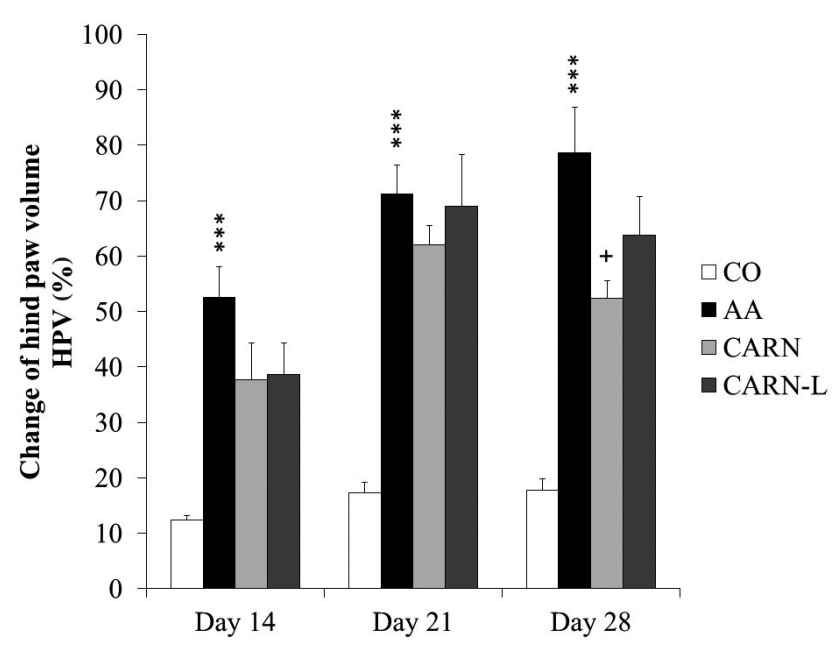

Figure 1. Change of hind paw volume (HPV) in adjuvant arthritis and the effect of carnosine and liposomal carnosine. Data are expressed as mean \pm SEM; $n=8 .^{* * *} p<0.001 v s$. healthy control, $+p<0.05$ vs. AA group. CO, control group; AA, adjuvant arthritis group; CARN, adjuvant arthritis group with administered carnosine; CARN-L, adjuvant arthritis group with administered liposomal carnosine. significantly decreased IL- $1 \beta$ concentration in plasma to the basal level analyzed in healthy animals (Table 2). Further arthritis significantly increased MMP-9 and MCP-1 in plasma on day 14 (Table 2 and Fig. 2). Carnosine and liposomal carnosine were effective in reducing significantly the MMP-9 levels (Table 2). Concerning MCP-1 in plasma, only liposomal carnosine (Fig. 2) reduced the levels of this parameter significantly. Thus liposomal carnosine was generally more effective in improving the inflammation analyzed in plasma than carnosine.

\section{Antioxidant capacity of carnosine and liposomal carnosine in plasma and brain tissue homogenate}

Plasma: Neither AA nor carnosine administered changed the content of lipid hydroperoxide (data not shown). However, AA significantly reduced the resistance to $\mathrm{Fe}^{2+}$ induced oxidation and both liposomal and non-liposomal carnosine were able to effectively increase it. In comparison to carnosine, liposomal carnosine was much more effective (Fig. 3). Oxidation of plasmatic proteins was assayed as protein carbonyls, which were increased in untreated arthritic animals. Carnosine and its liposomal form administered decreased effectively the protein carbonyls to control level. The arthritic process increased lipid peroxidation in plasma detected as levels of MDA and HNE. Carnosine and liposomal carnosine reduced the levels of MDA and both forms of carnosine studied were also able to decrease HNE to control level (Table 3).

Brain: The content of lipid hydroperoxides was increased in animals with AA without significance. Carnosine and

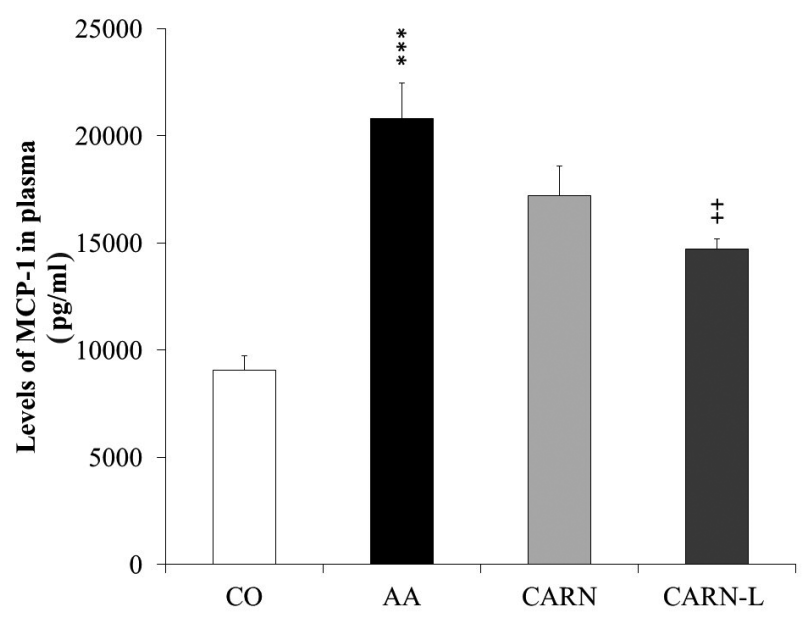

Figure 2. Inflammatory marker monocyte chemoattractant protein-1 MCP-1 measured in plasma on day 14. Data are expressed as mean \pm SEM; $n=8 .{ }^{* * *} p<0.001 v s$. healthy control, ${ }^{++} p<0.05$ $v s$. AA group. For abbreviations, see Fig. 1. 
Table 2. Parameters of inflammation measured in plasma on day 14. Level of interleukin $1 \beta$ (IL-1 $\beta$ ) and matrix metalloproteinase 9 (MMP-9)

\begin{tabular}{lrccc}
\hline \multirow{2}{*}{ Inflammatory parameters } & \multicolumn{4}{c}{ Group } \\
\cline { 2 - 5 } & \multicolumn{5}{c}{ CO } & AA & CARN & CARN-L \\
\hline IL-1 $\beta(\mathrm{pg} / \mathrm{ml})$ & $7.46 \pm 0.75$ & $94.49 \pm 26.32^{* *}$ & $17.24 \pm 3.05^{++}$ & $17.18 \pm 3.90^{++}$ \\
MMP-9 $(\mathrm{ng} / \mathrm{ml})$ & $37.88 \pm 3.55$ & $133.57 \pm 9.31^{\star * *}$ & $60.59 \pm 6.18^{+++}$ & $64.55 \pm 9.17^{+++}$ \\
\hline
\end{tabular}

$\mathrm{CO}$, control group; AA, adjuvant arthritis group; CARN, adjuvant arthritis group administered with carnosine; CARN-L, adjuvant arthritis group administered with liposomal carnosine. Data are expressed as mean $\pm \mathrm{SEM} ; n=8 .{ }^{* *} p<0.01 v s$. CO, ${ }^{* *} p<0.001$ vs. CO, ${ }^{++} p<0.01 v s . \mathrm{AA},{ }^{+++} p<0.001 v s . \mathrm{AA}$.

liposomal carnosine administered decreased the signal for damaged lipids (data not shown). Arthritis in experimental animals significantly reduced the resistance to $\mathrm{Fe}^{2+}$-induced oxidation and both forms of carnosine administered were able to increase it effectively, with liposomal carnosine being even more effective (Fig. 3). Protein carbonyls were increased in the brain of untreated arthritic animals, though not significantly. Carnosine and liposomal carnosine decreased brain protein carbonyls. Lipid peroxidation in the brain measured as content of MDA was increased 2-times in arthritic animals in comparison to healthy control. Both forms of carnosine administered reduced the content of MDA to control level. Moreover, HNE content was increased due to arthritis. Carnosine and liposomal carnosine were able to decrease this parameter significantly (Table 4).

Generally, the antioxidant effect of liposomal carnosine in plasma was stronger than that of carnosine. This trend was not observed in the brain.

\section{Effect of carnosine and liposomal carnosine on mRNA expression of iNOS in rat cartilage tissue}

In our study, the expression of iNOS mRNA was significantly increased in untreated arthritic animals (Fig. 4). The administration of carnosine did not lead to changes in mRNA expression of iNOS. Liposomal carnosine reduced this parameter without statistical significance.

\section{Discussion}

We intend to find new substances of natural origin with anti-inflammatory and antioxidant effect in AA. In an experimental study (Ponist et al. 2016) we investigated the effect of carnosine in vitro and in vivo, using two different animal models. The results indicated its potential systemic anti-inflammatory effects. It still remains unclear if the ability of carnosine to restore redox balance is the only mechanism

Table 3. Parameters of oxidative stress measured in plasma on day 28. Level of protein carbonyls, malondialdehyde (MDA) and 4-hydroxynonenal (HNE)

\begin{tabular}{lcccc}
\hline & \multicolumn{4}{c}{ Group } \\
\cline { 2 - 5 } & CO & AA & CARN & CARN-L \\
\hline Carbonyls $(\mu \mathrm{g} / \mathrm{ml})$ & $391.2 \pm 14.34$ & $457.72 \pm 11.09^{* * *}$ & $393.36 \pm 2.21^{+++}$ & $392.62 \pm 3.6^{+++}$ \\
MDA $(\mu \mathrm{g} / \mathrm{ml})$ & $2.4 \pm 0.39$ & $5.79 \pm 0.44^{* * *}$ & $2.9 \pm 0.25^{++}$ & $2.11 \pm 0.32^{+++}$ \\
HNE $(\mathrm{ng} / \mathrm{ml})$ & $1.54 \pm 0.16$ & $2.5 \pm 0.19^{* * *}$ & $1.5 \pm 0.07^{+++}$ & $1.55 \pm 0.09^{+++}$ \\
\hline
\end{tabular}

Data are expressed as mean $\pm \mathrm{SEM} ; \mathrm{n}=8 .{ }^{* *} p<0.001$ vs. $\mathrm{CO},{ }^{++} p<0.01$ vs. AA, ${ }^{+++} p<0.001$ vs. AA. For abbreviations, see Tab. 2.

Table 4. Parameters of oxidative stress measured in brain on day 28. Content of protein carbonyls, malondialdehyde (MDA) and 4-hydroxynonenal (HNE)

\begin{tabular}{lcccc}
\hline & \multicolumn{4}{c}{ Group } \\
\cline { 2 - 4 } & CO & AA & CARN & CARN-L \\
\hline Carbonyls $(\mu \mathrm{g} / \mathrm{g}$ tissue) & $548.07 \pm 15.0$ & $606.12 \pm 74.2$ & $475.4 \pm 10.6^{+}$ & $470.2 \pm 8.0^{+}$ \\
MDA $(\mu \mathrm{g} / \mathrm{g}$ tissue) & $5.38 \pm 0.73$ & $10.12 \pm 1.01^{* * *}$ & $3.45 \pm 0.23^{+++}$ & $5.52 \pm 0.8^{+++}$ \\
HNE $(\mathrm{ng} / \mathrm{g}$ tissue) & $3.26 \pm 0.17$ & $4.78 \pm 0.5^{* *}$ & $3.22 \pm 0.15^{++}$ & $3.54 \pm 0.23^{+}$ \\
\hline Data are expressed as mean \pm SEM; $\mathrm{n}=8^{* *} p<0.01 v s . \mathrm{CO},{ }^{* * *} p<0.001 v s . \mathrm{CO}^{+}{ }^{+} p<0.05 v s$. AA, ${ }^{++} p<0.01 v s$. AA, ${ }^{+++} p<0.001 v s$. \\
AA. For abbreviations, see Tab. 2.
\end{tabular}




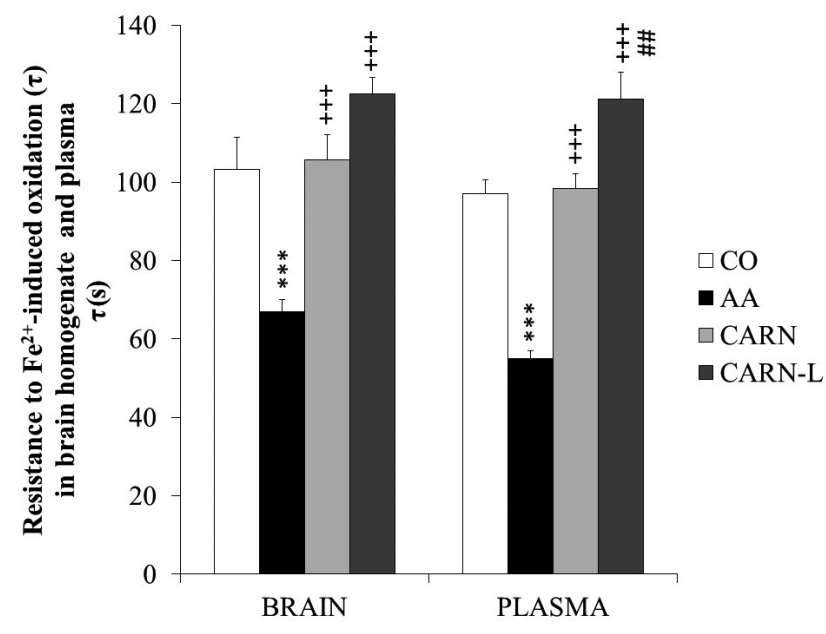

Figure 3. Resistance to $\mathrm{Fe}^{2+}$-induced oxidation $(\tau)$ in brain homogenate and plasma on day 28 . Data are expressed as mean \pm SEM; $n=8 .{ }^{* * *} p<0.001 v s$. healthy control, ${ }^{+++} p<0.001 v s$. AA group, ${ }^{\# \#} p<0.01$ vs. CARN group. For abbreviations, see Fig. 1.

responsible for its anti-inflammatory effects in AA. One goal of this research was to assess whether drug-delivery systems, such as liposomes, could improve the therapeutic potency and bioavailability of carnosine.

Several researchers have focused on the application of liposomes as drug carriers in the treatment of RA (Kapoor et al. 2014). In this study, we monitored AA progression by using the change of HPV. Liposomal carnosine reduced HPV change on both experimental days similarly as did carnosine. Moreover, carnosine reduced hind paw edema significantly on day 28. Topical application of mannitol exerted a potent and fast anti-edema effect in a rat model of joint inflammation, suggesting a possible utilization in patients affected by RA (Cavone et al. 2012). Intravenous therapy with liposomal dexamethasone phosphate (DxM-P) suppressed joint swelling in a significant, dose-dependent, and long-lasting manner and showed superior therapeutic efficacy compared to matched doses of free DxM-P (Anderson et al. 2010). Thus liposomal encapsulation of current anti-rheumatic drugs, and of new potential substances for RA treatment, concerning also other drug-delivery systems, may clearly potentiate the clinical efficacy of the compounds evaluated.

Monitoring of cytokines, chemokines and other proinflammatory mediators which play essential roles in the progression of inflammatory diseases is very important for evaluation of the effectivity of the treatment. For determination of inflammation in our study, we assessed plasmatic levels of cytokine IL-1 $\beta$, chemokine MCP-1 and protease MMP-9. IL-1 is the first molecule occurring at high levels in the synovial tissue in this T-cell-dependent arthritis. The early phases of the disease seem to be characterized by a systemic increase in IL-1 $\beta$ (Ferraccioli et al. 2010). Monocytes, macrophages and dendritic cells, as well as neutrophils, are among the immune cells capable of producing large amounts of IL-1 $\beta$ (Wilson et al. 1994; Thornberry et al. 1992). Arthritic animals demonstrated a significant increase in neutrophil numbers on day 14 in AA (Perecko et al. 2013). It seems, that neutrophils are important producers of IL- $1 \beta$ in AA. We found in literature, that carnosine decreased more than by $50 \%$ the production of ROS measured by luminol-dependent chemiluminescence of PMA-stimulated human neutrophils (Sharonov et al. 1990). Therefore, we assume, carnosine and liposomal carnosine inhibited the activity of neutrophils and their production IL- $1 \beta$. From our results, we can conclude, liposomal form of carnosine has no effect on the ability of carnosine to reduce the level of IL-1 $\beta$. Carnosine and liposomal carnosine decreased the IL- $1 \beta$ to basal level. It is possible that both carnosine forms are affecting the function of macrophages, which produce IL- $1 \beta$. In one of our previous studies, both high- and low-molecular-weight non-animal chondroitin sulphate were effective in reducing plasmatic levels of proinflammatory cytokines in AA, including IL-1 $\beta$ (Bauerova et al. 2014). Carnosine and its liposomal form might be good candidates for decrease of IL-1 levels in patients with RA.

MCP-1 may play an important role in the recruitment of peripheral blood leukocytes into the RA joints. Data from a study performed in RA patients provide evidence that the chemokine signalling pathway is involved in MCP-1 expression in the patients' tissues, which may contribute to chronic inflammation associated with RA. Targeting this signalling pathway may provide a novel therapeutic direction in RA (Zhang et al. 2015). Liposomal carnosine significantly decreased the plasmatic level of MCP-1 on

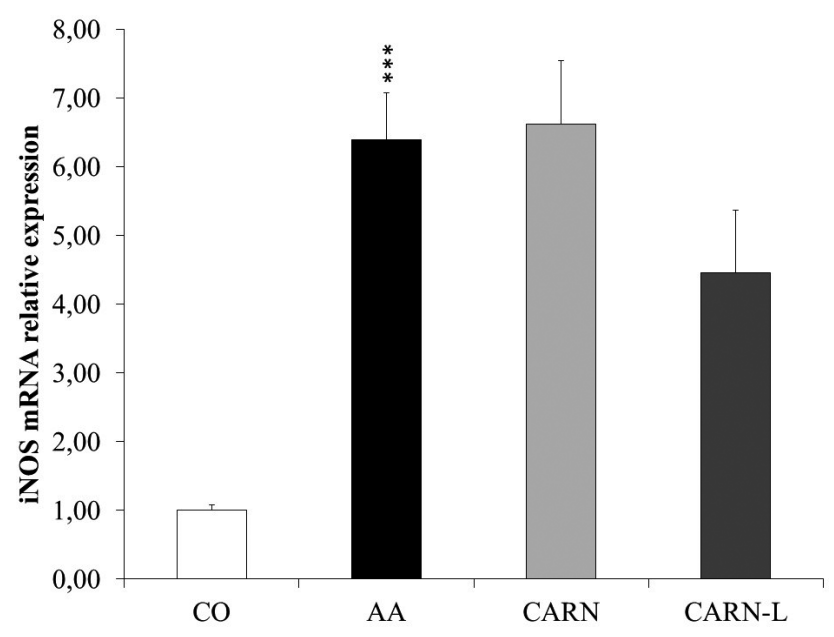

Figure 4. Relative changes of inducible nitric oxide synthase iNOS mRNA expression normalized to $\beta$-actin mRNA in arthritic rat cartilage tissue. Data are expressed as mean \pm SEM; $n=8 .{ }^{* * \star} p<$ $0.001 v s$. healthy control. For abbreviations, see Fig. 1. 
day 14 , while carnosine failed to affect it. It seems that incorporation of carnosine into liposomes increases its ability to reduce MCP-1 levels in plasma during AA development. Liposomal carnosine may play some role in the pathway of MCP-1 signalling.

Matrix metalloproteinases (MMPs) produced by macrophages and synovial fibroblasts were shown to be involved in the destruction of articular tissues in RA (Cunnane et al. 2014). Tumor necrosis factor- $\alpha$ (TNF- $\alpha$ ), interleukin- $1 \beta$ (IL$1 \beta$ ) and IL- 6 can regulate MMPs gene expression (Malemud and Schulte 2008). Since production of MMPs is controlled by TNF- $\alpha$, the use anti-TNF agents has been suggested in the treatment of RA (Klimiuk et al. 2004). In our study, both forms of carnosine were significantly effective in reducing MMP-9 in plasma. This ability of liposomal and nonliposomal carnosine might be also involved in the decrease of IL-1 $\beta$ plasmatic levels to basal values. Unfortunately, the results from the hind paw volume of animals for carnosine and liposomal carnosine do not correspond well with the intensive reduction of IL- $1 \beta$ plasmatic levels on day 14 . This might be explained by the fact that not only IL- $1 \beta$ but also TNF- $\alpha$ and IL- 6 regulate MMP-9 gene expression.

In animal models of RA, increased oxidative stress has been well documented by other authors (Wruck et al. 2011; Ahmed et al. 2015). In our study, oxidative stress in AA was analyzed by parameters in brain homogenates and in blood plasma. Lipid peroxidation is one of the major consequences of oxidative stress and leads to the production of conjugated diene hydroperoxides and unstable substances, which disintegrate into various bioactive aldehydes such as MDA and HNE (Phaniendra et al. 2015). Another important consequence of oxidative damage in RA is the deleterious effect on proteins, as free radicals can modify both their structure and functions (Dalle-Donne et al. 2006). Carnosine and liposomal carnosine significantly corrected all parameters of oxidation stress measured in plasma, except the content of lipid hydroperoxides. Liposomal carnosine was better in corrections of oxidative stress in plasma than carnosine, only in the resistance to $\mathrm{Fe}^{2+}$-induced oxidation. There was no difference in the ability of carnosine and liposomal carnosine to protect the proteins and lipids in plasma against oxidation.

$\mathrm{RA}$ is not a disease typically involving the CNS, but brain dysfunctions occur in 20 to $30 \%$ of rheumatic patients (Appenzeller et al. 2004). There are only few studies describing oxidative stress and brain damage during experimental arthritis such as AA (Skurlova et al. 2010; Skurlova et al. 2011; de Almeida Gonçalves et al. 2015). Carnosine is accumulated in excitable tissues (brain, heart and skeletal muscles) of vertebrates in large amounts (Abe 1995). In in vitro experiments carnosine protected brain neurons against oxidative injury (Boldyrev et al. 1999). Liposomes are widely used as carriers or delivery vehicles for therapeutic agents/ drugs to transport them to specific sites inside the human body (e.g. brain). Liposomes could be the carrier system for the drugs, they do not cross the blood brain barrier (Spuch and Navarro 2011). We therefore evaluated the effect of liposomal and non-liposomal carnosine on oxidative stress in brain homogenates. Our results with carnosine and liposomal carnosine showed protective ability of both forms of carnosine against protein and lipid oxidation. They corrected the resistance to $\mathrm{Fe}^{2+}$-induced oxidation in arthritic animals. Liposomal carnosine was more effective than carnosine but the difference was without significance.

We also evaluated mRNA expression of iNOS in the cartilage tissue of rats with AA. The inducible isoform of NOS is found in the synovial tissue and cartilage and its expression is regulated by catabolic cytokines, such as IL- $1 \beta$ and TNF- $\alpha$ (Amin et al. 1999). A preclinical study indicated that NO generation by iNOS induced in chondrocytes was a key event in the induction of AA (Yonekura et al. 2003). The results obtained in our experiment showed that only the liposomal form of carnosine decreased mRNA expression of iNOS in AA, and that not significantly. Liposomes can be assumed to improve bioavailability of carnosine in the rat cartilage tissue.

To the best of our knowledge, this is the first report in literature evaluating liposomal carnosine in AA. In an animal model of RA, the obtained results demonstrated that subcutaneously administered liposomal carnosine ameliorated all parameters of inflammation and oxidative stress measured. Moreover, in comparison with its non-liposomal form, liposomal carnosine was more effective in several parameters, especially MCP-1, the resistance to $\mathrm{Fe}^{2+}$-induced oxidation in plasma and brain homogenates, and the mRNA expression of iNOS in rat cartilage tissue. Liposomal carnosine showed a beneficial effect in AA, pointing to its potential use in the treatment of RA in humans.

Acknowledgements. This work was supported by the grant from VEGA 2/0044/15, APVV-15-0308 and bilateral SAS-RAMS project 2013-2015 coordinated by Dr. Bauerova (Slovakia) and Dr. Fedorova (Russia). Special thanks are due to Ing. Danica Mihalova and Jana Urgosova for their technical assistance.

\section{References}

Abe H. (1995): Histidine-related dipeptides: distribution, metabolism and physiological function. In: Biochemistry and Molecular Biology of Fishes. (Eds. Hochachka P. W., Mommsen T. P.), pp. $310-333$ https://doi.org/10.1016/S1873-0140(06)80017-2

Ahmed Y. M., Messiha B. A., Abo-Saif A. A. (2015): Protective effects of simvastatin and hesperidin against complete Freund's adjuvant-induced rheumatoid arthritis in rats. Pharmacology 96, 217-225 https://doi.org/10.1159/000439538 
Amin A. R., Attur M., Abramson S. B. (1999): Nitric oxide synthase and cyclooxygenases: distribution, regulation, and intervention in arthritis. Curr. Opin. Rheumatol. 11, 202-209 https://doi.org/10.1097/00002281-199905000-00009

Anderson R., Franch A., Castell M., Perez-Cano F. J., Bräuer R., Pohlers D., Gajda M., Siskos A. P., Katsila T., Tamvakopoulos C., Rauchhaus U., Panzner S., Kinne R. W. (2010): Liposomal encapsulation enhances and prolongs the anti-inflammatory effects of water-soluble dexamethasone phosphate in experimental adjuvant arthritis. Arthritis Res. 12, R147 https://doi.org/10.1186/ar3089

Appenzeller S., Bertolo M. B., Costallat L. T. (2004): Cognitive impairment in rheumatoid arthritis. Methods Find. Exp. Clin. Pharmacol. 5, 339-343 https://doi.org/10.1358/mf.2004.26.5.831324

Bauerová K., Bezek A. (1999): Role of reactive oxygen and nitrogen species in etiopathogenesis of rheumatoid arthritis. Gen. Physiol. Biophys. 18, 15-20

Bauerova K., Ponist S., Kuncirova V., Drafi F., Mihalova D., Paulovicova E., Volpi N. (2014): Effect of nonanimal high- and low-molecular-mass chondroitin sulfates produced by a biotechnological process in an animal model of polyarthritis. Pharmacology 94, 109-114 https://doi.org/10.1159/000366285

Boldyrev A. A., Song R., Lawrence D., Carpenter D. O. (1999): Carnosine protects against excitotoxic cell death independently of effects on reactive oxygen species. Neuroscience 94, 571-577 https://doi.org/10.1016/S0306-4522(99)00273-0

Boldyrev A., Johnson P. (2002): Carnosine and related compounds: antioxidant dipeptides. In: Oxidative Stress at Molecular, Cellular and Organ Levels. (Eds. Boldyrev A., Johnson P.), pp. 101-113, Research Signpost, Trivandrum, India

Cameron M., Gagnier J. J., Little C. V., Parsons T. J., Bluemle A., Chrubasik S. (2009): Evidence of effectiveness of herbal medicinal products in the treatment of arthritis. Part 1: Osteoarthritis. Phytother. Res. 23, 1497-1515 https://doi.org/10.1002/ptr.3007

Cavone L., Calosi L., Cinci L., Moroni F., Chiarugi A. (2012): Topical mannitol reduces inflammatory edema in a rat model of arthritis. Pharmacology 89, 18-21 https://doi.org/10.1159/000335094

Cross A., Barnes T., Bucknall R. C., Edwards S. W., Moots R. J. (2006): Neutrophil apoptosis in rheumatoid arthritis is regulated by local oxygen tensions within joints. J. Leukoc. Biol. 80, 521-528 https://doi.org/10.1189/jlb.0306178

Cunnane G., FitzGerald O., Beeton C., Cawston T. E., Bresnihan B. (2014): Early joint erosions and serum levels of matrix metalloproteinase $\mathbf{1}$, matrix metalloproteinase $\mathbf{3}$, and tissue inhibitor of metalloproteinases 1 in rheumatoid arthritis. Arthritis Rheum. 4, 2263-2274

Dalle-Donne I., Rossi R., Colombo R., Giustarini D., Milzani A. (2006): Biomarkers of oxidative damage in human disease. Clin. Chemistry 52, 601-623 https://doi.org/10.1373/clinchem.2005.061408

de Almeida Gonçalves G., de Sá-Nakanishi A. B., Wendt M. M., Comar J. F., Bersani Amado C. A., Bracht A., Peralta R. M. (2015): Green tea extract improves the oxidative state of the liver and brain in rats with adjuvant-induced arthritis. Food Funct. 6, 2701-2711 https://doi.org/10.1039/C5FO00548E

Dobrota D., Fedorova T., Stvolinsky S., Babushikova E., Likavcanova K., Drgova A., Strapkova A., Boldyrev A. (2005): Carnosine protects the brain of rats and mongolian gerbils against ischemic injury: after-stroke-effect. Neurochem. Res. 30, 1283-1288 https://doi.org/10.1007/s11064-005-8799-7

Drabikova K., Perecko T., Nosal R., Bauerova K., Ponist S., Mihalova D., Kogan G., Jancinova V. (2009): Glucomannan reduces neutrophil free radical production in vitro and in rats with adjuvant arthritis. Pharmacol. Res. 59, 399-403 https://doi.org/10.1016/j.phrs.2009.02.003

Fedorova T. N., Boldyrev A. A., Gannushkina I. V. (1999): Lipid peroxidation in experimental ischemia of the brain. Biochemistry $64,75-79$

Ferraccioli G., Bracci-Laudiero L., Alivernini S., Gremese E., Tolusso B., de Benedetti F. (2010): Interleukin-1 and interleukin-6 in arthritis animal models: roles in the early phase of transition from acute to chronic inflammation and relevance for human rheumatoid arthritis. Mol. Med. 16, 552-557 https://doi.org/10.2119/molmed.2010.00067

Helmick C. G., Felson D. T., Lawrence R. C., Gabriel S., Hirsch R., Kwoh C. K., Liang M. H., Kremers H. M., Mayes M. D., Merkel P. A. et al. (2008): Estimates of the prevalence of arthritis and other rheumatic conditions in the United States. Part I. Arthritis Rheum. 58, 15-25 https://doi.org/10.1002/art.23177

Kapoor B., Singh S. K., Gulati M., Gupta R., Vaidya Y. (2014): Application of liposomes in treatment of rheumatoid arthritis: quo vadis. ScientificWorldJournal 2014, 978351 https://doi.org/10.1155/2014/978351

Khojah H. M., Ahmed S., Abdel-Rahman M. S., Hamza A. B. (2016): Reactive oxygen and nitrogen species in patients with rheumatoid arthritis as potential biomarkers for disease activity and the role of antioxidants. Free Radic. Biol. Med. 97, 285-291 https://doi.org/10.1016/j.freeradbiomed.2016.06.020

Klimiuk P. A., Sierakowski S., Domyslawska I., Chwiecko J. (2004): Effect of repeated infliximab therapy on serum matrix metalloproteinases and tissue inhibitors of metalloproteinases in patients with rheumatoid arthritis. J. Rheumatol. 31, 238-242

Malemud C. J., Schulte M. E. (2008): Is there a final common pathway for arthritis? Future Rheumatol. 3, 253-268 https://doi.org/10.2217/17460816.3.3.253

Mateen S., Moin S., Zafar A., Khan A. Q. (2016): Redox signaling in rheumatoid arthritis and the preventive role of polyphenols. Clin. Chim. Acta 463, 4-10 https://doi.org/10.1016/j.cca.2016.10.007

Min J., Senut M. C., Rajanikant K., Greenberg E., Bandagi R., Zemke D., Mousa A., Kassab M., Farooq M. U., Gupta R., Majid A. (2008): Differential neuroprotective effects of carnosine, anserine, and $\mathrm{N}$-acetyl carnosine against permanent focal ischemia. J. Neurosci. Res. 86, 2984-2991 https://doi.org/10.1002/jnr.21744

Nosal R., Jancinova V., Petríkova M., Ponist S., Bauerova K. (2007): Suppression of oxidative burst of neutrophils with methotrexate in rat adjuvant arthritis. Chem. Letters 101, 243-244 
Pegova A., Abe H., Boldyrev A. (2000): Hydrolysis of carnosine and related compounds. Comp. Biochem. Physiol. B. Biochem. Mol. Biol. 127, 443-446 https://doi.org/10.1016/S0305-0491(00)00279-0

Perecko T., Drabikova K., Lojek A., Ciz M., Ponist S., Bauerova K., Nosal R., Harmatha J., Jancinova V. (2013): The effects of pterostilbene on neutrophil activity in experimental model of arthritis. Biomed. Res. Int. 2013, 106041 https://doi.org/10.1155/2013/106041

Phaniendra A., Jestadi D. B., Periyasamy L. (2015): „Free radicals: properties, sources, targets, and their implication in various diseases“. Indian J. Clin. Biochem. 30, 11-26 https://doi.org/10.1007/s12291-014-0446-0

Ponist S., Drafi F., Kuncirova V., Mihalova D., Rackova L., Danisovic L., Ondrejickova O., Tumova I., Truova O., Fedorova T., Bauerova K. (2016): Effect of carnosine in experimental arthritis and on primary culture chondrocytes. Oxid. Med. Cell. Longev. 2016, 8470589 https://doi.org/10.1155/2016/8470589

Schuber F., Kichler A., Boeckler C., Frisch B. (1998): Liposomes: from membrane models to gene therapy. Pure Appl. Chem. 70, 89-96 https://doi.org/10.1351/pac199870010089

Sharonov B. P., Govorova N. J., Lyzlova S. N. (1990): Carnosine as a potential scavenger of oxidants generated by stimulated neutrophils. Biochem. Int. 21, 61-68

Skurlova M., Stofkova A., Jurcovicova J. (2011): Anxiety-like behavior in the elevated-plus maze tests and enhanced IL-1 $\beta$, IL-6, NADPH oxidase- 1 , and iNOS mRNAs in the hippocampus during early stage of adjuvant arthritis in rats. Neurosci. Lett. 487, 250-254 https://doi.org/10.1016/j.neulet.2010.10.032

Skurlova M., Stofkova A., Kiss A., Belacek J., Pecha O., Deykun K., Jurcovicova J. (2010): Transient anorexia, hyper-nociception and cognitive impairment in early adjuvant arthritis in rats. Endocr. Regul. 44, 165-173 https://doi.org/10.4149/endo_2010_04_165

Spuch C., Navarro C. (2011): Liposomes for targeted delivery of active agents against neurodegenerative diseases (Alzheimer's disease and Parkinson's disease). J. Drug Deliv. 2011, 469679 https://doi.org/10.1155/2011/469679
Thornberry N.A., Bull H. G., Calaycay J. R., Chapman K. T., Howard A. D., Kostura M. J., Miller D. K., Molineaux S. M., Weidner J. R., Aunins J. et al. (1992): A novel heterodimeric cysteine protease is required for interleukin- $1 \beta$ processing in monocytes. Nature 356, 768-774 https://doi.org/10.1038/356768a0

Wilson K. P., Black J. A., Thomson J. A., Kim E. E., Griffith J. P., Navia M. A., Murcko M. A., Chambers S. P., Aldape R. A., Raybuck S. A. et al. (1994): Structure and mechanism of interleukin- $1 \beta$ converting enzyme. Nature 370, 270-275 https://doi.org/10.1038/370270a0

Winer J., Jung C. K. S., Shackel I., Williams P. M. (1999): Development and validation of real-time quantitative reverse transcriptase-polymerase chain reaction for monitoring gene expression in cardiac myocytes in vitro. Anal. Biochem. 270, 41-49 https://doi.org/10.1006/abio.1999.4085

Wruck C. J., Fragoulis A., Gurzynski A., Brandenburg L. O., Kan Y. W., Chan K., Hassenpflug J., Freitag-Wolf S., Varoga D., Lipross S., Pufe T. (2011): Role of oxidative stress in rheumatoid arthritis: insights from the Nrf2-knockout mice. Ann. Rheum. Dis. 70, 844-850 https://doi.org/10.1136/ard.2010.132720

Yonekura Y., Koshiishi I., Yamada K., Mori A., Uchida S., Nakamura T., Utsumi H. (2003): Association between the expression of inducible nitric oxide synthase by chondrocytes and its nitric oxide-generating activity in adjuvant arthritis in rats. Nitric Oxide 8, 164-169 https://doi.org/10.1016/S1089-8603(03)00025-9

Zacharias E. (2011): Suntres liposomal antioxidants for protection against oxidant-induced damage. J. Toxicol., 152474

Zhang L., Yu M., Deng J., Lv X., Liu J., Xiao Y., Yang W., Zhang Y., Li C. (2015): Chemokine signaling pathway involved in CCL2 expression in patients with rheumatoid arthritis. Yonsei Med. J. 56, 1134-1142 https://doi.org/10.3349/ymj.2015.56.4.1134

Received: March 8, 2017

Final version accepted: April 3, 2017

First published online: August 24, 2017 